\title{
Pancreas-on-a-Chip Technology for Transplantation Applications
}

\author{
Shadab Abadpour ${ }^{1,2} \cdot$ Aleksandra Aizenshtadt $^{2} \cdot$ Petter Angell Olsen $^{2} \cdot$ Kayoko Shoji $^{2} \cdot$ Steven Ray Wilson ${ }^{2,3}$. \\ Stefan Krauss ${ }^{2,4} \cdot$ Hanne Scholz ${ }^{1,2}$
}

Accepted: 26 October 2020 / Published online: 18 November 2020

(C) The Author(s) 2020

\begin{abstract}
Purpose of Review Human pancreas-on-a-chip (PoC) technology is quickly advancing as a platform for complex in vitro modeling of islet physiology. This review summarizes the current progress and evaluates the possibility of using this technology for clinical islet transplantation.

Recent Findings PoC microfluidic platforms have mainly shown proof of principle for long-term culturing of islets to study islet function in a standardized format. Advancement in microfluidic design by using imaging-compatible biomaterials and biosensor technology might provide a novel future tool for predicting islet transplantation outcome. Progress in combining islets with other tissue types gives a possibility to study diabetic interventions in a minimal equivalent in vitro environment.

Summary Although the field of $\mathrm{PoC}$ is still in its infancy, considerable progress in the development of functional systems has brought the technology on the verge of a general applicable tool that may be used to study islet quality and to replace animal testing in the development of diabetes interventions.
\end{abstract}

Keywords Islet transplantation · Pancreas transplantation · Stem cell-derived beta-like cells · Type 1 diabetes · Organ-on-a-chip · Microfluidic systems $\cdot$ Pancreas-on-a-chip $\cdot$ Multi-organ-on-a-chip

\section{Introduction}

Type 1 diabetes (T1D), which is mainly referred to as the insulin-dependent disease, results from an immune-mediated destruction of beta cells within the pancreatic islets [1]. Exogenous insulin therapy has shown to be effective to maintain the glucose homeostasis and reduce the complications associated with T1D, but it poorly mimics the normal beta cell function and comes with the risk of hypoglycemic episodes [2]. Beta cell replacement therapy in the form of both pancreas transplantation and allogeneic islet transplantation has proven to be a safe alternative treatment to external insulin

This article is part of the Topical Collection on Immunology, Transplantation, and Regenerative Medicine

Hanne Scholz

hanne.scholz@medisin.uio.no

Shadab Abadpour

Shadab.abadpour@rr-research.no

Aleksandra Aizenshtadt

aleksandra.aizenshtadt@medisin.uio.no

Petter Angell Olsen

peteraol@medisin.uio.no

Kayoko Shoji

kayoko.shoji@medisin.uio.no

Steven Ray Wilson

s.r.h.wilson@kjemi.uio.no
Stefan Krauss

stefan.krauss@medisin.uio.no

1 Department of Transplant Medicine and Institute for Surgical Research, Oslo University Hospital, Post Box 4950, Nydalen, N-0424 Oslo, Norway

2 Hybrid Technology Hub-Centre of Excellence, Institute of Basic Medical Sciences, University of Oslo, Oslo, Norway

Department of Chemistry, University of Oslo, Oslo, Norway

4 Institute of Immunology, Oslo University Hospital, Oslo, Norway 
administration, offering more precise control over blood glucose, reducing incidents of unaware hypoglycemia, and improving quality of life in patients with T1D [3]. The indications for beta cell therapy and factors influencing the chosen strategy are not covered by this review and can be read elsewhere [4]. For pancreas and islet transplantations, the procurement of the donor organ is an essential upstream step for the success of the islet isolation procedure and for graft survival [5]. Advances of organ preservation using ex vivo machine perfusion technologies show that organs can be kept viable outside the organisms for extended time period and contribute to achieve better viability and improvement in graft function [6-8].

For islet transplantation, existing procedures involve isolation and purification of the islets from the rest of the pancreatic tissue which often leads to ischemic damage and a proinflammatory signature [9]. Prior to transplantation, islet quality is evaluated mainly by measurements of number of islets, sterility, purity, and viability. Depending on the release criteria at different centers, this also includes potency assays such as static or dynamic glucose-stimulated insulin secretion followed by a calculation of the stimulation index (SI). Commonly, SI $>1$ is considered as enough evidence for a sufficient response of the isolated islets to blood glucose [10-12]. Unfortunately, this test does not necessarily correlate with the clinical outcome after islet transplantation, probably due to a variability of in vitro environmental factors [13].

Due to the limitations of suitable immune-matching donor tissue in terms of quantity and quality, as well as time and geographic limitations between the availability of donor material and acceptor readiness, alternatives are being explored. The last decade has mobilized significant resources for developing an unlimited source of insulin-producing cells that can be used for transplantation [14]. Strategies have primarily been based on attempts to glucose responsive cells through differentiation protocols starting from embryonic stem cells (ESCs) or pluripotent stem cells (PSCs) [15].

Immune compatibility is a central issue in all transplantation regimes. Although strategies such as encapsulation of islets or stem cell-derived beta-like cells enable the transplantation of cells without the need for immune suppression [16], these strategies are still under development. There has also been evidence showing that even autologous induced pluripotent stem cell (iPSC) differentiation and transplantation to patients could create immune responses in recipients [17]. Therefore, the use of immunosuppressive medications is an inevitable step [18, 19]. Establishment of the best available immunosuppressive regimen is challenging mainly due to the direct toxicity of immunosuppressive medications on islet viability and glucose responsiveness [20,21].

While in vitro differentiation of stem cells to beta-like cells is slowly improving, awareness about the importance of the micro-environment of the beta cells and its standardized supply of oxygen, nutrition, and other factors is raising. Hence, platforms that provide a controlled microenvironment and enable rigid standardization of surrounding conditions are being developed.

Pancreas-on-a-chip (PoC), which refers mainly to the study of endocrine part of the pancreas on microfluidic chip, may be used as a standardized and real-time assessment platform for evaluating islet potency and quality. Organ-on-a-chip (OoC) technology, in general, promises to provide a test and interrogation environment that might replace the complexity of an animal model. OoC is a microfluidic-based device enabling to culture and grow living cells and organoid substructures in a controlled micro-environment. Commonly, OoC platforms recapitulate one or more aspects of the organ's dynamics, functionality, and in vivo (patho) physiological responses under real-time monitoring of different cultured tissue types [22]. The OoC technology has been developed, aiming for better prediction of the preclinical drug testing and reduction of the use of animal for the pharmaceutical industry [23, 24].

One of the first papers on using cells in microfluidic platform was published in 1991, reporting a construction of a ventricular myocardium on a microfluidic system, which enables the first biophysical analysis of heart in vitro [25]. The first microfluidic platform to study the interaction of lung and liver tissue was introduced in 2004 [26•]. Since then, a range of microfluidics have been developed, mimicking diverse biological function of various tissue types including muscles, bones, liver, lung, brain, gut, and kidney [27].

OoC-based systems have the potential to be used for a range of applications such as personalized organ function and dysfunction, as well as pharmacological interventions that are particularly difficult to study in an isolated 2D or 3D in vitro laboratory setting. PoC devices that enable in a minimal equivalent environment to mimic the function of islets in particular may enable us to gain new information on the islet physiology and the impact of therapeutic interventions. Importantly, PoC technology also promises to advance standardization and quality control of the islets or stem cell-derived beta-like cells per se for replacement therapy. In this review, we will present the various developments toward $\mathrm{PoC}$ platforms and discuss the use of this technology for clinical transplantation.

\section{Pancreas-on-a-Chip Designs}

The design of the chip depends largely on the function of the organ. Therefore, each organ type needs individualized system to mimic its micro-environment. Microfluidic platforms for islets may have trapping sites in which islets are immobilized and cultured under medium flow [28•]. Trapping of islets is mostly done by micro-wells [29•, 30 , $31,32 \cdot, 33-35]$ or by constrictions [36••, 37-40] that are fabricated in micro-channels under continuous flow. Using such 
microfluidic platforms, islet viability and composition as well as hormone and metabolite secretions by islets could be tested "on-chip". Perfusion is essential to maintain the viability of trapped islets, removal of metabolic products, and stimulation of islets with chemicals, hormones, and nutrients such as glucose. Precise fluid control is crucial to minimize any damage to the trapped islets and to analyze hormone kinetics in relation to biochemical and metabolic stimulation in the islets. Jun et al. have developed a microfluidic perfusion system providing an osmosis-driven low-speed flow (1.54-5.04 $\mu \mathrm{m} / \mathrm{s}) \mathrm{com}$ parable to in vivo interstitial flow levels. This allows culturing re-aggregated islet in "concave" micro-wells for a month with low flow rate that could prevent shear force damage to cells and provide continuous oxygen and nutrient supplies for islets. This model aids studying islet function post-isolation and has a potential to be used as an in vitro model for diabetic drug testing [29••]. Physical protection of islets from flow within a chip platform by placing islets in a micromesh sheet has also been reported as a strategy to avoid damaging of islets by shear force while allowing perfusion of oxygen and nutrient to the islet in the chip [41].

Size heterogeneity of isolated islets $(50-400 \mu \mathrm{m})$ reduces the viability of islets in microfluidic chip due to the fact that large islets could damage in a greater extent by the flow rate. Therefore, having islets with different sizes in microfluidic platform could create challenges in the amount of oxygen and nutrient that islets need [42]. It has been shown that smaller islets perform better than large islets both in clinical settings [43] and in culture [44]. Standardization of islet size by engineering size-controlled cell clusters is one strategy to overcome the variation in oxygen and nutrient demand by islets in microfluidic platform and also flow rate damage in the system [45].

\section{Pancreas-on-a-Chip Application for Islet Quality Control Post-Isolation}

Islet viability could be adversely affected by numerous factors during organ procurement and isolation procedure. These negative events increase the number of required islets posttransplantation in order to achieve insulin independence. Having reliable methods to study islet potency post-isolation could attribute to better evaluation of islet quality postisolation (Fig. 1). Currently, an in vitro glucose-stimulated insulin secretion assay is widely used for assessing islet

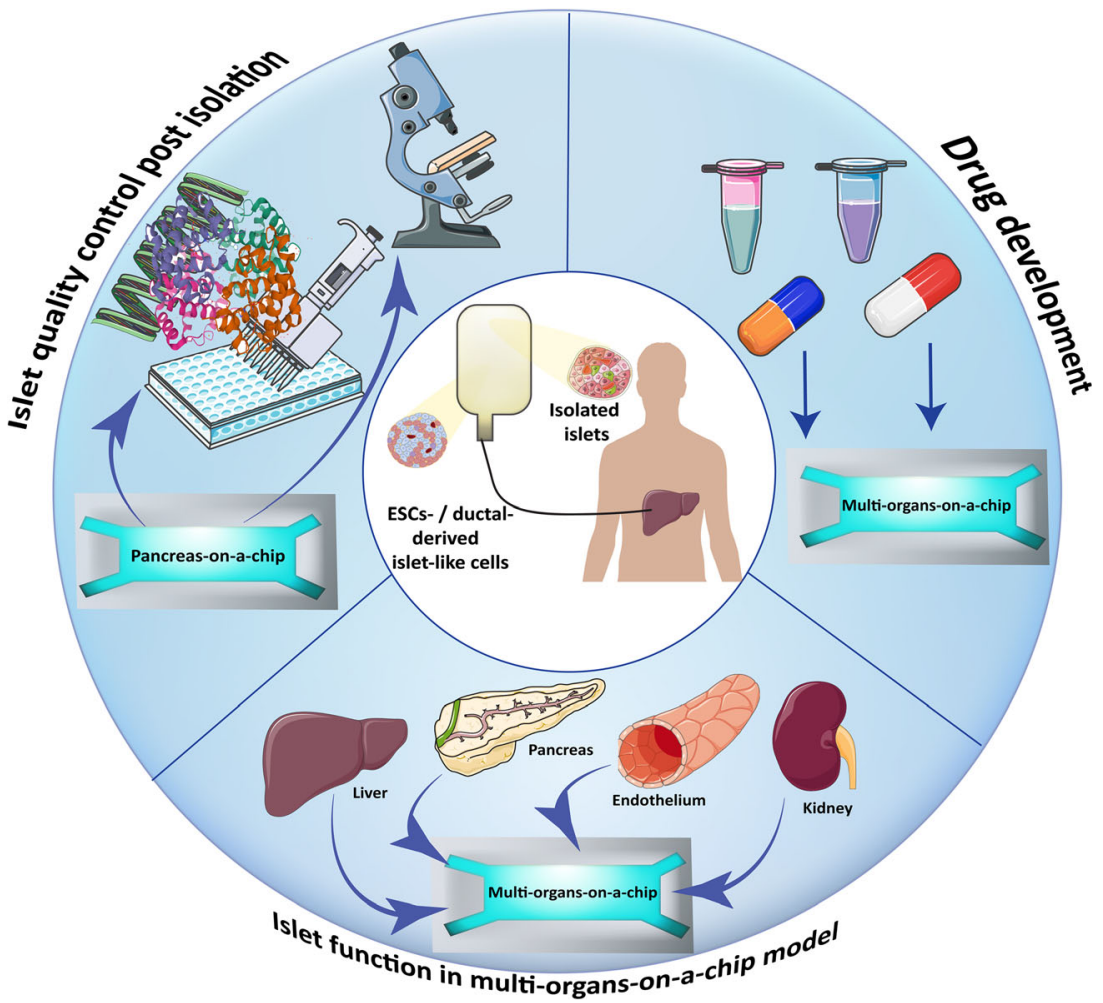

Fig. 1 Pancreas-on-a-chip application for diabetes and islet transplantation research. Pancreas-on-a-chip platforms not only could be used as a system to perform islet quality control post-isolation procedure, but also can be used to investigate stem cell-derived betalike cell function and compare them with primary islets in a standardized platform. Islet quality control in a standardized microfluidic platform could give one more comprehensive understanding of the isolated islet quality and function and predict outcome of the islet transplantation. Combining islets or stem cellderived beta-like cells on chip with other organoids for example liver, kidney, or endothelial tissue not only increases our knowledge on islet function and their interactions with other tissue types, but also could be used as a valuable system for drug development including diabetesrelated and immunosuppressive medications 
quality post-isolation procedure, and the results of this assay are considered as exclusion criteria for clinical islet transplantation in type 1 diabetic patients. However, it has been reported that poor insulin release in response to glucose in human islets does not necessarily predict the in vivo function of islet post-transplantation [46], and this method alone could not be used for studying islet potency post-isolation.

Transplanting isolated islets to a diabetic mouse model is also considered as a method to assess islet potency in reversing blood glucose and diabetic condition. However, this is a retrospect manner as it takes more than 30 days to get the information about islet quality. Therefore, this method could not be used as a quality control for isolated islets prior to transplantation. In addition, other factors such as the time of performing in vivo glucose response test and blood glucose measurements are important. Most of the analyses for evaluating islet grafts are performed during day; however, rodents are nocturnal animals and are more active during night. This affects the transplanted islet graft response and the result of islet quality control [47].

Several research groups have been developing microfluidic devices for evaluating islet function including islet response to glucose and insulin secretion, intracellular $\mathrm{Ca}^{2+}$, islet membrane capacities, and oxygen consumption rate (Table 1) [53-56]. The first microfluidic device designed to be used for human islet evaluation post-isolation is a polydimethylsiloxane (PDMS)-based device in which 100 islets are infused into a device with $7 \mathrm{~mm}$ diameter [32•]. The device has wells on the bottom with $500 \mu \mathrm{m}$ diameter for trapping and culturing islets. The device is perfused using peristaltic pumps for circulating the culture media and glucose solutions for performing dynamic glucose responsiveness and $\mathrm{Ca}^{2+}$ measurement tests [32•].

The most common methods for analyzing secreted insulin by islets, either in standard culture or in microfluidic platforms, are capillary electrophoresis-based immunoassays (CEIA) and intracellular $\mathrm{Ca}^{2+}$ oscillation monitoring [29・•, 30, 31 , 33 , 34 , 40, 57]. Lomasney et al. have applied CEIA in a glass chip to detect insulin and islet amyloid polypeptide [31]. The chip has also flow switching feature that enable switching the glucose concentration every $5 \mathrm{~s}$. Another method for detection of insulin secreted by islets is $\mathrm{Ca}^{2+}$ oscillation, which could visualize the exocytosis of insulin using fluorescent dyes and allows measurement of secreted insulin in response to stimulated glucose instantly and hence could be used as a pre-evaluation method in post islet isolation $[29 \bullet \bullet, 30,32 \bullet, 35,40]$. One of the disadvantages with most of the microfluidic devices is the sample size. Requiring a large number of islets makes these devices not suitable for quality control of islets post-isolation. Microfluidic devices with integrated biosensors in the form of extracellular electrodes engulfed to plasma membrane have been developed in order to provide a possibility to study and detect islet function from few numbers of islets in chip platform [48]. These biosensors have the ability to detect action potential in response to different concentration of glucose [48]. Some devices offer single islet sensitivity devices, which minimize the number of islets required for post-isolation functionality assessment [34]. Some of these microfluidic platforms have integrated automated systems for samplings, which gives the possibility of performing dynamic glucose-stimulated insulin test and detection of both prominent first phase and sustainable pulsatile second phase of insulin secretion [58].

Despite advances in the design of microfluidic devices, traditional sampling and liquid handling followed by ELISA quantification are still predominant. Glieberman et al. developed a fully automated polycarbonate-based device with integrated "on chip" insulin immunoassay [36••]. Implementing the insulin immunoassay detection reduces the required time and cost of sampling and analyzing secreted insulin by islets, which could make this device scalable for large applications. In addition, the presented device has a high sensitivity in detection of insulin. Therefore, it needs only a few numbers of islets with the possibility to retrieve the islets after glucose stimulation test for further analysis. Such a device gives also a possibility to customize the ELISA assay implemented in the device in order to measure other physiologically relevant stimulus such as incretin and glucagon [36••].

Recently, studies have reported the assessment of islet quality using oxygen consumption rate (OCR) [59, 60]. Moreover, the calculation of ATP/ADP ratio in addition to OCR measurement and glucose-stimulated insulin secretion assay is considered as a method for evaluating islet potency [61]. Analysis of islet viability post-isolation using measurement of miRNAs in particular miRNA-375 and also studying the DNA methylation pattern on insulin promoter have been reported to correlate with the outcome of islet transplantation [62].

A recently published study reported a new microfluidic device in which islets are cultured separately in islet-packets. The device is see-through which gives the possibility of imaging the cells while performing functionality analysis such as OCR and insulin measurements. The islets could be lysed inside the device for further analysis of gene expressions, measurement of DNA methylation, and miRNA secretion by islets $[49,63]$.

Various microfluidic platforms have been designed using see-through materials in order to provide imaging opportunity of the cultured islets [64]. Integrating live-cell imaging technologies such as Raman imaging to the chip platform provide an excellent feature for non-destructive in situ imaging of islets in PoC system. Using this technology, one could visualize islet response to glucose and other stimulus as well as cell death stages, which all give better understanding of islet quality post-isolation [28•]. 
Table 1 Generated PoC platforms and possible application of these platform in islet research

\begin{tabular}{|c|c|c|c|c|}
\hline Model & $\begin{array}{l}\text { Material in } \\
\text { chip }\end{array}$ & Purpose & Outcome & Ref \\
\hline $\begin{array}{l}\text { Human and } \\
\text { mouse } \\
\text { pancreatic } \\
\text { islets }\end{array}$ & PDMS & $\begin{array}{l}\text { Microfluidic platform to study isolated islet function } \\
\text { by measuring insulin secretion in response to } \\
\text { glucose and fluorescent imaging of the } \\
\text { mitochondrial membrane potential and } \\
\text { intracellular calcium. }\end{array}$ & $\begin{array}{l}\text { First microfluidic perfusion chamber for islets that } \\
\text { allow study of dynamic insulin secretion in } \\
\text { response to glucose and intracellular calcium } \\
\text { measurement upon glucose challenge. }\end{array}$ & {$[32 \bullet]$} \\
\hline $\begin{array}{l}\mathrm{C} 57 \mathrm{BL} / 6 \text { mice } \\
\text { islets }\end{array}$ & PDMS & $\begin{array}{l}\text { Online and real-time analysis of islet membrane } \\
\text { action potential using integrated biosensors to the } \\
\text { PoC platform. }\end{array}$ & $\begin{array}{l}\text { Using only few islets, the chip with integrated } \\
\text { biosensors allow measurement of membrane } \\
\text { action potentials in islets upon treatment with } \\
\text { different glucose concentrations. This platform } \\
\text { could be combined with insulin analysis test to } \\
\text { give a better overview of islet health. }\end{array}$ & {$[48]$} \\
\hline $\begin{array}{l}\text { Sprague-Dawley } \\
\text { rat islets }\end{array}$ & PDMS & $\begin{array}{l}\text { Dynamic culturing of islet spheroids under interstitial } \\
\text { flow condition to reduce shear cell damage in } \\
\text { microfluidic chip. }\end{array}$ & $\begin{array}{l}\text { Dynamic culture of islet spheroids enhanced islet } \\
\text { function and maintained islet endothelial cells up } \\
\text { to } 30 \text { days inside the chip. This system increased } \\
\text { reconstitution of islet extracellular matrix. The } \\
\text { proposed model has a potential to be used as } \\
\text { platform for following islet function post-isolation } \\
\text { and also to be used as an in vitro model for testing } \\
\text { diabetic medications. }\end{array}$ & {$[29 \bullet \bullet]$} \\
\hline $\begin{array}{l}\text { MIN6 } \\
\text { psuedo-islets } \\
\text { and isolated } \\
\text { mouse islets. }\end{array}$ & $\begin{array}{l}\text { Borosilicate } \\
\text { glass }\end{array}$ & $\begin{array}{l}\text { Using a see-through material for simultaneous } \\
\text { measurement of fluorescence and oxygen } \\
\text { consumption rate in a PoC model. }\end{array}$ & $\begin{array}{l}\text { The platform enabled measurement of oxygen } \\
\text { consumption, } \mathrm{NAD}(\mathrm{P}) \mathrm{H} \text { auto-fluorescence, } \\
\text { cytosolic } \mathrm{Ca}^{2+} \text { concentration, and insulin secretion } \\
\text { by islets. }\end{array}$ & [49] \\
\hline $\begin{array}{l}\text { Pancreatic } \\
\text { human islets }\end{array}$ & Polycarbonate & $\begin{array}{l}\text { Generation of microfluidic chip for islets with } \\
\text { automated islet loading, direct glucose stimulation } \\
\text { chip, and integrated insulin detection assay inside } \\
\text { the chip. }\end{array}$ & $\begin{array}{l}\text { This microfluidic chip provides a synchronized } \\
\text { glucose stimulation and continuous insulin } \\
\text { detection using an on-chip immunoassay. Using } \\
\text { this system, there is no need for sampling. The } \\
\text { platform is see-though which gives the possibility } \\
\text { for imaging the islets inside the chip. This platform } \\
\text { is made of polycarbonate which does not have the } \\
\text { negative impact of PDMS on cultured islets. }\end{array}$ & {$[36 \bullet \bullet$} \\
\hline iPS cells & PDMS & $\begin{array}{l}\text { Multi-layer microfluidic platform for in situ } \\
\text { differentiation of iPSCs to islet organoids. }\end{array}$ & $\begin{array}{l}\text { Direct aggregation and differentiation of iPSCs to } \\
\text { beta- and alpha-like cells. Cells expressed } \\
\text { endocrine transcription markers. They were } \\
\text { positive for insulin and c-peptide protein } \\
\text { expressions and responsive to glucose stimulation. }\end{array}$ & {$[50]$} \\
\hline $\begin{array}{l}\text { EndoC- } \beta \mathrm{H} 3 \\
\quad \text { cells }\end{array}$ & PDMS & $\begin{array}{l}\text { Generation of microfluidic chip with self-guided } \\
\text { trapping sites for human pseudo-islets in order to } \\
\text { monitor insulin secretion kinetics and study } \\
\text { pseudo-islet functionality using Raman } \\
\text { microscopy. }\end{array}$ & $\begin{array}{l}\text { Real-time monitoring of islets using Raman } \\
\text { microscopy as well as dynamic sampling for } \\
\text { biphasic glucose-stimulated insulin response } \\
\text { analysis. Raman microscopy not only allowed } \\
\text { tracing islet glucose responsiveness, but also } \\
\text { visualized molecule structures such as lipids and } \\
\text { gave a possibility to study mitochondrial activity. }\end{array}$ & {$[28 \bullet]$} \\
\hline $\begin{array}{l}\text { C57BL6 mice } \\
\text { islets }\end{array}$ & PDMS & $\begin{array}{l}\text { Developing microfluidic chip with a range of flow } \\
\text { rate in order to improve culture medium exchange } \\
\text { inside the islets and increase survival of the } \\
\text { endothelial cells with pancreatic tissue. }\end{array}$ & $\begin{array}{l}\text { Adjusted flow rate inside the chip resulted in double } \\
\text { increase in endothelial density in islets compared } \\
\text { to the classical culture system. The islets showed } \\
\text { improvement in glucose-stimulated } \mathrm{Ca}^{2+} \text { response } \\
\text { and insulin secretion. }\end{array}$ & {$[51]$} \\
\hline $\begin{array}{l}\text { Human } \\
\text { pancreatic } \\
\text { islets }\end{array}$ & PDMS & $\begin{array}{l}\text { Interaction of human primary pancreatic islets and } \\
\text { liver spheroids using a microfluidic chip. }\end{array}$ & $\begin{array}{l}\text { Co-culturing islets and liver organoids in } \\
\text { microfluidic chip maintains the tissue function up } \\
\text { to } 15 \text { days. Functional coupling of islets and liver } \\
\text { tissue demonstrated insulin release in response to } \\
\text { glucose by islets and promoted glucose uptake by } \\
\text { liver organoids. The model could be used to study } \\
\text { the effect of various diabetic medications on } \\
\text { glucose regulation. }\end{array}$ & {$[52 \bullet]$} \\
\hline
\end{tabular}




\section{Pancreas-on-a-Chip Application for Drug Development}

In vitro studies for drug development mainly use cell culture protocols in which cells are grown on 2-dimensional (2D) monolayer in a well-defined culture medium. However, culturing cells in 2D is opposed to the cell micro-environment in living organisms, where all cells are in three-dimensional (3D) environment and have cell-cell and cell-extracellular matrix (ECM) interactions. ECM plays a critical role in determining the function and behavior of cells. In the context of the pancreas, interactions between the highly innervated and vascularized islets and the surrounding ECM are central for optimal insulin production and glucose responsiveness [65].

Animal models provide 3D cell micro-environment; however, the success rate of translating the results to human clinical trials have been noticeably low due to the major evolutionary differences between human and animal model. OoC technologies have a potential to mitigate several of the current limitations regarding the animal models and the in vitro studies in $2 \mathrm{D}$ systems by providing a standardized $3 \mathrm{D}$ culture system for human-relevant studies in a condition mimicking the cell micro-environment in vivo (Fig. 1).

Immunosuppressive medication which is an inevitable part of the islet transplantation could also get benefit from OoC technologies. OoC devices can provide a platform for testing the compatibility of the immunosuppressive regimen with immune system [66-69], as well as the effect of the immunosuppressive reagents on isolated islet function and viability [70]. OoC technologies have been used for studying the effect of immunosuppressive medications, tacrolimus, and cyclosporine $\mathrm{A}$ on $\mathrm{T}$ cell interactions and adhesion to endothelial adhesion molecules [71]. Rodrigues-Moncayo et al. developed a microfluidic chip with integrated biosensors that automatically measures interleukin-8 and tumor necrosis factor-alpha secretion from a consistent number of blood-derived monocytes, neutrophils, and THP-1 monocytes [66]. Such devices could be used for studying instant blood-mediated inflammatory reaction (IBMIR) and auto- and allo-immunity. They also give researchers an opportunity to investigate the effect of immunosuppressive reagents on insulin secretion in response to glucose $[19,72]$. Future development of microfluidic platforms for islets together with compartments of immune systems and other tissue types especially liver tissue provide an opportunity to study the effect of immunosuppressive regimen on glucose metabolism and insulin secretion in a more standardized setting.

It should also be mentioned that in drug development efforts, it is desirable to perform direct measurements of drugs, drug metabolites, biomarkers of toxicity, etc. A common approach for such measurements is employing mass spectrometry (MS). The MS instrument allows analysis of small molecules (drugs, lipids, peptides) as well as larger biomolecules.
MS enables both identification and quantification of compounds. The instrument allows for same-run measurements of large numbers of compounds, for example in metabolomics and proteomics. MS is often dependent on coupling with electrospray ionization (ESI) unit which allows biomolecules to enter the MS in gas phase (a requirement for MS analysis). In addition, compounds must often be separated prior to ESIMS to secure ample sensitivity and secure identifications. This is typically performed using liquid chromatography (LC). Therefore, when mass spectrometry has been employed in bioanalysis/drug analysis, it is in reality a combination of these three techniques: LC-ESI-MS. However, LC-ESI-MS is as of today not commonly coupled with $\mathrm{OoC}$ technologies [73]. Common reasons are that online systems can be difficult to hyphenate due to incompatibilities (for example, 3D cell cultures can contain salts and proteins that can contaminate the LC-ESI-MS if a sample clean-up is not undertaken). In addition, the LC step can also dilute bio-fractions that may already be low in volume or analyst concentrations. Solutions to online coupling of OoC and LC-ESI-MS may lie in focus on online sample clean-up and reducing LC dilution. Regarding the former, one approach might be to incorporate electromembrane extraction, which is essentially an electrophoresis across an oil membrane. Initial efforts in combining EME and 3D models have recently been described and show promise for online action. Regarding the latter, drug analysis can potentially be undertaken using miniaturized LC columns, which are routinely used in, e.g., proteomics [74]. In any case, approaches to coupling OoC and mass spectrometry will be technically challenging but can strengthen the data output in drug development efforts.

\section{Generation of Multi-Organ-on-a-Chip for Islet Research}

Organ-on-a-chip platform gives a possibility to combine and culture different cell types in separate culture compartments and connect them through microfluidic channels in order to mimic and study the cross-talk between two or more organs [75]. The concept is known as multi-organ-on-a-chip (MoC) or body-on-a-chip. However, each organ has its own specificity that needs to be considered in chip design in order to mimic the organ micro-environment. The more similar the physiology and property of organs are to each other, the easier and reliable the chip becomes to the native tissue. The Shuler research group is one of the pioneers in the field of $\mathrm{MoC}$. They have developed $\mathrm{MoC}$ with multiple organ chambers called micro cell culture analog for co-culturing lung, liver, and tumor tissue to study the effect of anti-cancer medications on these tissue types [26•, 76, 77]. Imura and colleagues developed an $\mathrm{MoC}$ device for integrating breast cancer cells, small intestine, and liver [78] as well as integrating kidney 
tissue [79] for studying the absorption rate and therapeutic mechanisms of anti-cancer medications. There has been attempt of combining pancreatic islets and liver hepatocytes to investigate the physiological regulation of circulation glucose by the biological source of insulin produced by pancreatic islets in the system [52•]. This system represents a 15 day co-culture of islet and liver spheroids in which functional islets responded to glucose load to the system and produced insulin. Secreted insulin promoted glucose uptake by liver spheroids, and as the glucose concentration fell, insulin secretion by islets also decreased, demonstrating a feedback loop between liver and islets [52•]. This platform could be a useful technique for studying the effect of specific medications including diabetic or immunosuppressive medications on transplanted islets and the effect on islet-liver communication.

Pancreatic islets are heavily vascularized in vivo with fenestrated endothelial cells (ECs) to facilitate blood glucose sensing and endocrine hormone secretion [37]. Islets possess a strong metabolic regulation of their blood perfusion. Of particular importance is adenosine and ATP/ADP. Basal and stimulated blood flows are modified by local endothelial mediators such as nitric oxide, the sympathetic/ parasympathetic innervation as well as gastrointestinal hormones [80]. The close proximity of insulin-secreting beta cells and ECs also play a critical role in modulating the proliferation and survival of both cell types [37]. During islet isolation procedure, islets lose their vascularized capillary, which consequently make them prone to hypoxia and could affect their endocrinal functions. Therefore, generation of vasculature network together with islets on $\mathrm{MoC}$ platform provides a possibility of mimicking the physiological interactions of islets with this network and other organs in MoC. Endothelium is not a planer surface but rather has tubular structures with various sizes, which could impose challenges in engineering of the microfluidic chips [81]. However, advances in soft lithography allow us to construct transparent microfluidic devices with micro-channels in which endothelial cells can be coated the inner surface of the channel to create blood vessel network [82].

For modeling blood vessels in vitro, human umbilical vein endothelial cells (HUVECs) are the popular choice due to their accessibility and vast knowledge regarding their expressing specific markers. There have been attempts in generating vasculature model on $\mathrm{MoC}$ together with different tissue types. Spheroids generated from lung fibroblast were cultured in a microfluidic chip with endothelial cells in the microchannel of the chip. This study has been shown successful angiogenesis of the endothelial cells toward lung tissue [83]. Stevens et al. has also created a model for liver vasculature using primary human hepatocytes and HUVEC cells. In this mode, liver organoids were combined with geometrically patterned human endothelial cells in a hydrogel that has the possibility to be implanted into a microfluidic device [84] (Fig. 1).
Blood vessels have the capability to sprout in vitro on a chip platform as shown by Duinen et al. [85]. This capability could be exploited in a two- or three-compartment chip format in which HUVEC cells or iPS-derived vascular endothelial cells are in one compartment, while parenchymal islet cells are in a second chamber separated by columns or a ridge. A third chamber may serve as a recipient for the vascular endothelial cells such as veins would do in the body. In this setting, endothelial cells may sprout into the target tissue and supply it with nutrition, oxygen, and physiological molecules such as glucose, hormones, and metabolites in a controlled way, and exit the molecules that are produced by islets into the venous system from where they can be measured. Indeed, Rambol et al. have recently presented a microfluidic system for islet vascularization [86] in which HUVECs were supported by mesenchymal stem cells (MSC) and formed perfusable endothelialized networks in a fibrin gel. Subsequent incorporation of isolated rat islets demonstrated that islets recruit local microvasculature in the device.

\section{Pancreas-on-a-Chip Application for Generation and Evaluation of Pluripotent Stem Cell- or Non-endocrine Pancreatic Cell-Derived Beta-like Cells}

Despite the impressive advances in the field of human islet isolation, scarcity of suitable donors for islet isolation procedure affects the amount of islets that can be used for research and for clinical islet transplantation. To target the shortage of pancreatic islets, alternative sources of cells including differentiation of stem cells and progenitor cells into insulinproducing beta cells or transdifferentiated non-endocrine cells to beta-like cells have been investigated over the years. Differentiation of ESCs or iPSCs toward specialized cell types is based on an in vitro recapitulation of the sequence of inductive signals that cells are exposed to during embryogenesis at different stages of tissue/organ development. From the first published stage-to-stage protocol in which human pluripotent stem cells were guided through developmental stages of the pancreas resulting in immature multi-hormone-expressing endocrine cells $[1,2,9,87]$ until now, the differentiation protocols were considerably improved in reaching partially functional beta-like cells [88-90]. As a result, for the first time, some of the ES-derived endocrine cells exhibited delayed and less prominent glucose-stimulated insulin secretion compared to the human islets [88], and these cells were able to reverse hyperglycemia in chemically induced diabetic mice [3].

OoC platforms can be used as a 3D culture method offering new alleys as highlighted by the importance of cell-to-matrix and cell-to-cell interactions as well as mechanical cues for the development of cell fates during the development of islets [91-93]. Re-aggregation or encapsulation of pancreatic 
progenitors or immature beta-like cells have been shown as one of the essential steps toward improving the maturation and functionality of stem cell-derived beta-like cells [94-96]. In particular, Velazco-Cruz et al. has reported improvement in glucose responsiveness of stem cell-derived beta-like cells as these cells were able to have both first and second phase of insulin release by generation of uniform-sized cell clusters [95]. A multi-layer OoC platform has been used for aggregation and differentiation of islet organoids containing alpha and beta cells. These cells expressed endocrine markers and were responsive to glucose-stimulated insulin secretion test [50].

Pancreatic islet survival and function are dependent on islet microvasculature network. During pancreatic development, endothelial, mesenchymal, and neuronal cells form the micro-environment required for proper organogenesis [97-99]. Moreover, within the endocrine part of the pancreatic tissue, insulin secretion by beta cells is affected by the paracrine signals produced by non-beta cell fraction of endocrine tissue [100-102]. Therefore, absence of micro-vasculature environment compromises functionality of stem cell-derived beta-like cells. Engineering organoids containing human islet and amniotic epithelial cells have been reported to improve organoid function and engraftment in type 1 diabetes mouse model [103]. These types of studies are yet to be done for generating uniform stem cell-derived organoids together with other cell types such as endothelial, neuronal, and mesenchymal cells in order to enhance function and vascularization of organoids. Combination of organoid engineering, 3D culture approaches, and microfluidic platforms could serve as a toolbox for recapitulating the precise spatio-temporal niche signals during pancreatic development as well as copying the dynamics of blood flow and mechanical forces during islet formation and functionality as a mature organ. Advancing of technologies could also help in deciphering of mechanisms coordinating endocrine cell clustering and islet formation.

Reprogramming pancreatic non-endocrine acinar or ductal cells to insulin-producing beta-like cells could be another approach for reducing the demand for beta cells. These cells could have extreme plasticity with a strong potential to be reprogrammed to insulin-producing beta-like cells [104, 105]. Although acinar cells have been shown to have a potential to generate insulin-positive cells, the state of acinar to ductal cell dedifferentiation was observed before endocrine reprogramming, which could suggests higher plasticity of ductal cells [106-109]. In addition, severe damage to pancreatic tissue such as acinar ablation and partial duct ligation (PDL) has been shown to induce differentiation toward endocrine lineages including beta cells. This evidence suggests the existence of a pancreatic progenitor pool within the ductal tree in the pancreas tissue $[110,111]$. Most of the current differentiation protocols are conducted in a 2D culture, followed by suspension aggregate cultures or cultures at an air-liquid interface [14]. Although, this approach works for stem cells during the early stages of differentiation protocol, it is worth mentioning that expansion and transdifferentiation of nonendocrine pancreatic cells to beta-like cells requires $3 \mathrm{D}$ culture system. Transdifferentiation and expansion of these cells in 2D culture system could hamper the differentiation process by transition of non-endocrine cells to mesenchymal cell-like phenotype during the culturing process $[112,113]$. Culturing duct progenitor cells in a matrigel-based 3D culture system has been shown to facilitate the differentiation of these cells to insulin-producing cells [114]. Hence, reprogramming of pancreatic non-endocrine cells to insulin-producing cells could also get benefit from $\mathrm{OoC}$ technologies.

\section{Challenges and Outlook}

PoC technology has recently become more accessible and robust. Although the field is still in its infancy, there have been huge efforts from the field of the microfluidic engineering to develop new and functional PoC platforms.

Materials for PoC fabrication need to support both the engineering of the device and cell survival. Most of the $\mathrm{PoC}$ devices are made of PDMS. The material is highly deformable, which makes it applicable to replicate structures at high resolution. It is also biocompatible, oxygen permeable, and optically transparent. All these factors make this material suitable for biological studies. However, the flexibility and gas exchange property of PDMS lead to evaporation of culture media. This is mainly problematic in $\mathrm{PoC}$ applications due to having small volume of the cell culture medium in these systems [115]. In addition, PDMS has been shown to absorb lipophilic compounds such as steroid hormones and various drugs affecting the islet analysis $[116,117]$. New materials are under development; however, they have not been widely used, and it could be beneficial to use various materials based on the application purpose.

Despite all the improvements in the field of engineering to create PoC platforms, designed chip systems need to meet specific biological requirements in order to mimic organs in multicellular organisms. Amount of cells/tissue on chip, the ratio of each tissue types in $\mathrm{MoC}$, and flow rate are some of the factors that could disturb the application of PoC models. The main biological issue is related to the source of cells that are introduced to PoC systems. Current human PoC formats are based on isolated islets from cadaver donors that are either used directly post-isolation or re-aggregated to a standard-sized format. In fact, human islets are limited due to their cost and few available donors. Therefore, human stem cell-derived beta-like cells are promising sources. However, in vitro differentiated beta-like cells have not reached enough metabolic maturity to be suitable for a truly physiological on-chip format. Moreover, isolated islets lack the exocrine part of the pancreas that surrounds them, in particular the ductal epithelium from which they have 
emerged during development and to which they are still attached [118-120]. Isolated islets do not contain components of the immune system that may surveillance and interact with them [120]. The same is true for in vitro-differentiated beta-like cells. Without those elements, PoCs will per se only be able to copy a limited set of physiological functions. This may not be a problem for pre-transplantation testing as the islets will be vascularized and innervated through the host after transplantation. However, for ex vivo islet models that shall be functioning as close as possible to in vivo, on-chip vascularization and innervation may be an interesting option.

Previously developed microfluidic models have used cell culture medium to provide various metabolites, nutrients, and oxygen for cells. However, different tissue types require different cell culture medium, and this issue becomes more serious when attempting culture of various tissue types in one platform. Therefore, finding a universal culture medium is an extremely urgent matter.

Complicated handling procedure of $\mathrm{PoC}$ devices greatly affects high-throughput, usability, and standardization of these devices. This imposes a major barrier to wider practical application of this technology. Most of the designed $\mathrm{PoC}$ platforms require many sample collections. This could disturb operation of the chip and also might change the concentration of various metabolites during the sampling procedure. Generating in situ monitoring systems and using sensors to monitor the situation of the islets in an automated manner could be a way to have standardized and more reliable systems.

PoC platform generation for islet research is a rapid developing area. A number of examples are cited in this review, demonstrating the advantages of having functional PoC systems to evaluate islet quality post-isolation. Developing PoCs that could better reflect the complexity of islets as a single tissue type or combined with other types of tissue on MoCs could create a platform for diabetes disease modeling and drug testing especially diabetic medications and immunosuppressive regimen which all could be beneficial for improving the outcome of islet transplantation procedure.

Funding Open Access funding provided by University of Oslo (incl Oslo University Hospital). Financial support for research on pancreas-on-achip in our laboratories was obtained from the Research Council of Norway through its Centres of Excellence funding scheme, project number 262613.

\section{Compliance with Ethical Standards}

Conflict of Interest The authors declare that they have no conflict of interest.

Human and Animal Rights and Informed Consent This article does not contain any studies with human or animal subjects performed by any of the authors.
Abbreviations ESC, Embryonic stem cell; IBMIR, Instant bloodmediated inflammatory reaction; iPSC, Induced pluripotent stem cell; T1D, Type 1 diabetes; OoC, Organ-on-a-chip; MoC, Multi-organ-on-achip; PoC, Pancreas-on-a-chip; ECM, Extracellular matrix; MS, Mass spectrometry; EC, Endothelial cells; HUVEC, Human umbilical vein endothelial cells

Open Access This article is licensed under a Creative Commons Attribution 4.0 International License, which permits use, sharing, adaptation, distribution and reproduction in any medium or format, as long as you give appropriate credit to the original author(s) and the source, provide a link to the Creative Commons licence, and indicate if changes were made. The images or other third party material in this article are included in the article's Creative Commons licence, unless indicated otherwise in a credit line to the material. If material is not included in the article's Creative Commons licence and your intended use is not permitted by statutory regulation or exceeds the permitted use, you will need to obtain permission directly from the copyright holder. To view a copy of this licence, visit http://creativecommons.org/licenses/by/4.0/.

\section{References}

Papers of particular interest, published recently, have been highlighted as:

- Of importance

•. Of major importance

1. D'Amour KA, Bang AG, Eliazer S, Kelly OG, Agulnick AD, Smart NG, et al. Production of pancreatic hormone-expressing endocrine cells from human embryonic stem cells. Nat Biotechnol. 2006;24(11):1392-401.

2. Basford CL, Prentice KJ, Hardy AB, Sarangi F, Micallef SJ, Li X, et al. The functional and molecular characterisation of human embryonic stem cell-derived insulin-positive cells compared with adult pancreatic beta cells. Diabetologia. 2012;55(2):358-71.

3. Kroon E, Martinson LA, Kadoya K, Bang AG, Kelly OG, Eliazer $\mathrm{S}$, et al. Pancreatic endoderm derived from human embryonic stem cells generates glucose-responsive insulin-secreting cells in vivo. Nat Biotechnol. 2008;26(4):443-52.

4. Wojtusciszyn A, Branchereau J, Esposito L, Badet L, Buron F, Chetboun $\mathrm{M}$, et al. Indications for islet or pancreatic transplantation: statement of the TREPID working group on behalf of the Societe francophone du diabete (SFD), Societe francaise d'endocrinologie (SFE), Societe francophone de transplantation (SFT) and Societe francaise de nephrologie - dialyse - transplantation (SFNDT). Diabetes Metab. 2019;45(3):224-37.

5. Lee TC, Barshes NR, Brunicardi FC, Alejandro R, Ricordi C, Nguyen L, et al. Procurement of the human pancreas for pancreatic islet transplantation. Transplantation. 2004;78(3):481-3.

6. Branchereau J, Renaudin K, Kervella D, Bernadet S, Karam G, Blancho G, et al. Hypothermic pulsatile perfusion of human pancreas: preliminary technical feasibility study based on histology. Cryobiology. 2018;85:56-62.

7. Leemkuil M, Lier G, Engelse MA, Ploeg RJ, de Koning EJP, 't Hart NA, et al. Hypothermic oxygenated machine perfusion of the human donor pancreas. Transplant Direct. 2018;4(10):e388.

8. Weissenbacher A, et al. The future of organ perfusion and reconditioning. Transpl Int. 2019;32(6):586-97.

9. Bruin JE, Erener S, Vela J, Hu X, Johnson JD, Kurata HT, et al. Characterization of polyhormonal insulin-producing cells derived in vitro from human embryonic stem cells. Stem Cell Res. 2014;12(1):194-208. 
10. Ricordi C, et al. National Institutes of Health-sponsored clinical islet transplantation consortium phase 3 trial: manufacture of a complex cellular product at Eight Processing Facilities (vol 65, pg 3418, 2016). Diabetes. 2017;66(9).

11. Street CN, Lakey JRT, Shapiro AMJ, Imes S, Rajotte RV, Ryan EA, et al. Islet graft assessment in the Edmonton protocol - implications for predicting long-term clinical outcome. Diabetes. 2004;53(12):3107-14.

12. Bertuzzi F, Ricordi C. Prediction of clinical outcome in islet allotransplantation. Diabetes Care. 2007;30(2):410-7.

13. Papas KK, Suszynski TM, Colton CK. Islet assessment for transplantation. Curr Opin Organ Transplant. 2009;14(6):674-82.

14. Tremmel DM, Mitchell SA, Sackett SD, Odorico JS. Mimicking nature-made beta cells: recent advances towards stem cell-derived islets. Curr Opin Organ Transplant. 2019;24(5):574-81.

15. Ghani MW, Ye L, Yi Z, Ghani H, Birmani MW, Nawab A, et al. Pancreatic beta-cell replacement: advances in protocols used for differentiation of pancreatic progenitors to beta-like cells. Folia Histochem Cytobiol. 2019;57(3):101-15.

16. Espes D, Lau J, Carlsson PO. Mechanisms in endocrinology: towards the clinical translation of stem cell therapy for type 1 diabetes. Eur J Endocrinol. 2017;177(4):R159-68.

17. Ye L, Li L, Wan B, Yang M, Hong J, Gu W, et al. Immune response after autologous hematopoietic stem cell transplantation in type 1 diabetes mellitus. Stem Cell Res Ther. 2017;8(1):90.

18. Amorese G, Lombardo C, Tudisco A, Iacopi S, Menonna F, Marchetti $\mathrm{P}$, et al. Induction and immunosuppressive management of pancreas transplant recipients. Curr Pharm Des. 2020;26:342539.

19. Vantyghem MC, de Koning EJP, Pattou F, Rickels MR. Advances in beta-cell replacement therapy for the treatment of type 1 diabetes. Lancet. 2019;394(10205):1274-85.

20. Berney T, Buhler LH, Majno P, Mentha G, Morel P. Immunosuppression for pancreatic islet transplantation. Transplant Proc. 2004;36(2 Suppl):362S-6S.

21. Kloster-Jensen K, Vethe NT, Bremer S, Abadpour S, Korsgren O, Foss $\mathrm{A}$, et al. Intracellular sirolimus concentration is reduced by tacrolimus in human pancreatic islets in vitro. Transpl Int. 2015;28(10):1152-61.

22. Marx U, et al. Biology-inspired microphysiological systems to advance patient benefit and animal welfare in drug development. ALTEX. 2020.

23. Jodat YA, Kang MG, Kiaee K, Kim GJ, Martinez AFH, Rosenkranz A, et al. Human-derived organ-on-a-chip for personalized drug development. Curr Pharm Des. 2018;24(45):5471-86.

24. Marx U, Andersson TB, Bahinski A, Beilmann M, Beken S, Cassee FR, et al. Biology-inspired microphysiological system approaches to solve the prediction dilemma of substance testing. ALTEX. 2016;33(3):272-321.

25. Rohr S, Scholly DM, Kleber AG. Patterned growth of neonatal rat heart cells in culture. Morphological and electrophysiological characterization. Circ Res. 1991;68(1):114-30.

26. Sin A, et al. The design and fabrication of three-chamber microscale cell culture analog devices with integrated dissolved oxygen sensors. Biotechnol Prog. 2004;20(1):338-45. This article reports the first microfluidic platform designed to study the interaction between to different tissue types, lung and liver tissue.

27. Zhang BY, et al. Advances in organ-on-a-chip engineering. Nat Rev Mater. 2018;3(8):257-78.

28. Zbinden A, et al. Non-invasive marker-independent high content analysis of a microphysiological human pancreas-on-a-chip model. Matrix Biol. 2020;85-86:205-20. This article presents a human pancreas-on-a-chip platform in which the functionality and glucose responsiveness of human pseudo-islets were monitored in situ using Raman imaging. The chip provides a platform to study the biphasic islet response to glucose as well as analysis of mitochondrial activity and lipid metabolism of this insulin responsive cells.

29.• Jun Y, et al. In vivo-mimicking microfluidic perfusion culture of pancreatic islet spheroids. Sci Adv. 2019;5(11):eaax4520. This article demonstrates a microfluidic platform with optimized flow condition which avoids the shear force damage on islets. The chip mimics interstitial flow conditions allowing the dynamic culture of pancreatic islets for 30 days in chip. The islets showed improved insulin secretion, reconstitution of islet extracellular matrix and maintenance of endothelial cells within islets.

30. Dhumpa R, Truong TM, Wang X, Bertram R, Roper MG. Negative feedback synchronizes islets of Langerhans. Biophys J. 2014;106(10):2275-82.

31. Lomasney AR, Yi L, Roper MG. Simultaneous monitoring of insulin and islet amyloid polypeptide secretion from islets of Langerhans on a microfluidic device. Anal Chem. 2013;85(16): 7919-25.

32 - Mohammed JS, et al. Microfluidic device for multimodal characterization of pancreatic islets. Lab Chip. 2009;9(1):97-106. The article presents the first microfluidic platform designed for evaluation of human islet quality post isolation procedure. The chip has trapping sites for islets and uses a low flow rate to avoid shear force on islets. the chip provides a platform to study islet response to glucose and insulin secretion in a standardized way.

33. Lee D, Wang Y, Mendoza-Elias JE, Adewola AF, Harvat TA, Kinzer K, et al. Dual microfluidic perifusion networks for concurrent islet perifusion and optical imaging. Biomed Microdevices. 2012;14(1):7-16.

34. Dishinger JF, Reid KR, Kennedy RT. Quantitative monitoring of insulin secretion from single islets of Langerhans in parallel on a microfluidic chip. Anal Chem. 2009;81(8):3119-27.

35. Lee $\mathrm{SH}$, et al. Microphysiological analysis platform of pancreatic islet $\beta$-cell spheroids. Adv Healthc Mater. 2018;7(2).

36.• Glieberman AL, et al. Synchronized stimulation and continuous insulin sensing in a microfluidic human islet on a chip designed for scalable manufacturing. Lab Chip. 2019;19(18):2993-3010. This study presents a microfluidic platform with in situ automated glucose stimulation of the islets. The chip has an integrated fluorescent glucose tracking and build-in insulin immunoassay which allows tracking of glucose stimulation and continuous insulin measurement of the islets inside the chip. The platform is made of polycarbonate in order to avoid the negative impact of normally used PDMS material on islets. The low flow rate also reduces shear force on the islets.

37. Silva PN, Green BJ, Altamentova SM, Rocheleau JV. A microfluidic device designed to induce media flow throughout pancreatic islets while limiting shear-induced damage. Lab Chip. 2013;13(22):4374-84.

38. Nourmohammadzadeh M, Lo JF, Bochenek M, Mendoza-Elias JE, Wang Q, Li Z, et al. Microfluidic array with integrated oxygenation control for real-time live-cell imaging: effect of hypoxia on physiology of microencapsulated pancreatic islets. Anal Chem. 2013;85(23):11240-9.

39. Lam AK, Silva PN, Altamentova SM, Rocheleau JV. Quantitative imaging of electron transfer flavoprotein autofluorescence reveals the dynamics of lipid partitioning in living pancreatic islets. Integr Biol (Camb). 2012;4(8):838-46.

40. Rocheleau JV, Walker GM, Head WS, McGuinness OP, Piston DW. Microfluidic glucose stimulation reveals limited coordination of intracellular $\mathrm{Ca} 2+$ activity oscillations in pancreatic islets. Proc Natl Acad Sci U S A. 2004;101(35):12899-903. 
41. Hori $\mathrm{T}$, et al. Compact fluidic system for functional assessment of pancreatic islets. Biomed Microdevices. 2019;21(4):91. https:// doi.org/10.1007/s10544-019-0443-4.

42. Buchwald P. FEM-based oxygen consumption and cell viability models for avascular pancreatic islets. Theor Biol Med Model. 2009;6:5.

43. Lehmann R, Zuellig RA, Kugelmeier P, Baenninger PB, Moritz $\mathrm{W}$, Perren A, et al. Superiority of small islets in human islet transplantation. Diabetes. 2007;56(3):594-603.

44. Kin T, Senior P, O'Gorman D, Richer B, Salam A, Shapiro AM. Risk factors for islet loss during culture prior to transplantation. Transpl Int. 2008;21(11):1029-35.

45. Yu Y, Gamble A, Pawlick R, Pepper AR, Salama B, Toms D, et al. Bioengineered human pseudoislets form efficiently from donated tissue, compare favourably with native islets in vitro and restore normoglycaemia in mice. Diabetologia. 2018;61(9): 2016-29.

46. Carroll PB, Ricordi C, Rilo HR, Fontes P, Khan R, Tzakis AG, et al. Intrahepatic human islet transplantation at the University-ofPittsburgh - results in 25 consecutive cases. Transplant Proc. 1992;24(6):3038-9.

47. Jennings RE, Berry AA, Strutt JP, Gerrard DT, Hanley NA. Human pancreas development. Development. 2015;142(18): 3126-37.

48. Perrier R, Pirog A, Jaffredo M, Gaitan J, Catargi B, Renaud S, et al. Bioelectronic organ-based sensor for microfluidic real-time analysis of the demand in insulin. Biosens Bioelectron. 2018;117: 253-9.

49. Schulze T, et al. A 3D microfluidic perfusion system made from glass for multiparametric analysis of stimulus-secretion coupling in pancreatic islets. Biomed Microdevices. 2017 Sep;19(3). https://doi.org/10.1007/s10544-017-0186-z.

50. Tao TT, et al. Engineering human islet organoids from iPSCs using an organ-on-chip platform. Lab Chip. 2019;19(6):948-58.

51. Sankar KS, Green BJ, Crocker AR, Verity JE, Altamentova SM, Rocheleau JV. Culturing pancreatic islets in microfluidic flow enhances morphology of the associated endothelial cells. PLoS One. 2011;6(9):e24904.

52. Bauer $\mathrm{S}$, et al. Functional coupling of human pancreatic islets and liver spheroids on-a-chip: towards a novel human ex vivo type 2 diabetes model. Sci Rep. 2017;7(1):14620. This study presents coupling of pancreatic human islets and human liver organoids in a multi-organ-on-a-chip platform. This platform provides a possibility of investigating islet response to glucose and insulin secretion as well as glucose uptake by the liver spheroids. The cells were maintained functional for up to $\mathbf{1 5}$ days within the chip. The chip is a perfusable platform and allows performing glucose tolerance tests on different time points. Such platforms could be used to study the effect of various medications including diabetic medications on glucose regulations and pancreas-liver cross-talk.

53. Dishinger JF, Kennedy RT. Serial immunoassays in parallel on a microfluidic chip for monitoring hormone secretion from living cells. Anal Chem. 2007;79(3):947-54.

54. Wang Y, Lo JF, Mendoza-Elias JE, Adewola AF, Harvat TA, Kinzer KP, et al. Application of microfluidic technology to pancreatic islet research: first decade of endeavor. Bioanalysis. 2010;2(10):1729-44.

55. Castiello FR, Heileman K, Tabrizian M. Microfluidic perfusion systems for secretion fingerprint analysis of pancreatic islets: applications, challenges and opportunities. Lab Chip. 2016;16(3): 409-31.

56. Chen W, Lisowski M, Khalil G, Sweet IR, Shen AQ. Microencapsulated 3-dimensional sensor for the measurement of oxygen in single isolated pancreatic islets. PLoS One. 2012;7(3):e33070.
57. Shackman JG, Reid KR, Dugan CE, Kennedy RT. Dynamic monitoring of glucagon secretion from living cells on a microfluidic chip. Anal Bioanal Chem. 2012;402(9):2797-803.

58. Misun PM, et al. In vitro platform for studying human insulin release dynamics of single pancreatic islet microtissues at high resolution. Adv Biosyst. 2020;4(3). https://doi.org/10.1002/adbi. 201900291.

59. Steurer W, Stadlmann S, Roberts K, Fischer M, Margreiter R, Gnaiger E. Quality assessment of isolated pancreatic rat islets by high-resolution respirometry. Transplant Proc. 1999;31(1-2):650.

60. Sweet IR, Khalil G, Wallen AR, Steedman M, Schenkman KA, Reems JA, et al. Continuous measurement of oxygen consumption by pancreatic islets. Diabetes Technol Ther. 2002;4(5):66172 .

61. Goto M, Holgersson J, Kumagai-Braesch M, Korsgren O. The ADP/ATP ratio: a novel predictive assay for quality assessment of isolated pancreatic islets. Am J Transplant. 2006;6(10):2483-7.

62. Lehmann-Werman R, Neiman D, Zemmour H, Moss J, Magenheim J, Vaknin-Dembinsky A, et al. Identification of tissue-specific cell death using methylation patterns of circulating DNA. Proc Natl Acad Sci U S A. 2016;113(13):E1826-34.

63. Lee $\mathrm{SH}$, et al. Microphysiological analysis platform of pancreatic islet $\beta$-cell spheroids. Adv Healthc Mater. 2018;7(2). https://doi. org/10.1002/adhm.201701111.

64. Makarov AY, Volkova YM, Shundrin LA, Dmitriev AA, Irtegova IG, Bagryanskaya IY, et al. Chemistry of Herz radicals: a new way to near-IR dyes with multiple long-lived and differently-coloured redox states. Chem Commun (Camb). 2020;56(5):727-30.

65. Aamodt KI, Powers AC. Signals in the pancreatic islet microenvironment influence -cell proliferation. Diabetes Obes Metab. 2017;19:124-36.

66. Rodriguez-Moncayo R, Jimenez-Valdes RJ, Gonzalez-Suarez AM, Garcia-Cordero JL. Integrated microfluidic device for functional secretory immunophenotyping of immune cells. ACS Sens. 2020;5(2):353-61.

67. Chen W, Huang NT, Oh B, Lam RHW, Fan R, Cornell TT, et al. Surface-micromachined microfiltration membranes for efficient isolation and functional immunophenotyping of subpopulations of immune cells. Adv Healthc Mater. 2013;2(7):965-75.

68. Stephens A, Nidetz R, Mesyngier N, Chung MT, Song Y, Fu J, et al. Mass-producible microporous silicon membranes for specific leukocyte subset isolation, immunophenotyping, and personalized immunomodulatory drug screening in vitro. Lab Chip. 2019;19(18):3065-76.

69. Huang NT, Chen W, Oh BR, Cornell TT, Shanley TP, Fu J, et al. An integrated microfluidic platform for in situ cellular cytokine secretion immunophenotyping. Lab Chip. 2012;12(20):4093101.

70. Gamble A, Pepper AR, Bruni A, Shapiro AMJ. The journey of islet cell transplantation and future development. Islets. 2018;10(2):80-94.

71. Kim SK, Moon WK, Park JY, Jung H. Inflammatory mimetic microfluidic chip by immobilization of cell adhesion molecules for T cell adhesion. Analyst. 2012;137(17):4062-8.

72. Vantyghem MC, Marcelli-Tourvielle S, Pattou F, Noël C. Effects of non-steroid immunosuppressive drugs on insulin secretion in transplantation. Ann Endocrinol (Paris). 2007;68(1):21-7.

73. Lin A, Sved Skottvoll F, Rayner S, Pedersen-Bjergaard S, Sullivan G, Krauss S, et al. 3D cell culture models and organon-a-chip: meet separation science and mass spectrometry. Electrophoresis. 2020;41(1-2):56-64.

74. Wilson SR, Olsen C, Lundanes E. Nano liquid chromatography columns. Analyst. 2019;144(24):7090-104.

75. Rogal J, Zbinden A, Schenke-Layland K, Loskill P. Stem-cell based organ-on-a-chip models for diabetes research. Adv Drug Deliv Rev. 2019;140:101-28. 
76. Sung JH, Shuler ML. A micro cell culture analog (microCCA) with 3-D hydrogel culture of multiple cell lines to assess metabolism-dependent cytotoxicity of anti-cancer drugs. Lab Chip. 2009;9(10):1385-94.

77. Sung JH, Kam C, Shuler ML. A microfluidic device for a pharmacokinetic-pharmacodynamic (PK-PD) model on a chip. Lab Chip. 2010;10(4):446-55.

78. Imura Y, Sato K, Yoshimura E. Micro total bioassay system for ingested substances: assessment of intestinal absorption, hepatic metabolism, and bioactivity. Anal Chem. 2010;82(24):9983-8.

79. Imura Y, Yoshimura E, Sato K. Microcirculation system with a dialysis part for bioassays evaluating anticancer activity and retention. Anal Chem. 2013;85(3):1683-8.

80. Jansson L, Carlsson PO. Pancreatic blood flow with special emphasis on blood perfusion of the islets of Langerhans. Compr Physiol. 2019;9(2):799-837.

81. Kimura H, Sakai Y, Fujii T. Organ/body-on-a-chip based on microfluidic technology for drug discovery. Drug Metab Pharmacokinet. 2018;33(1):43-8.

82. Lin DSY, Guo F, Zhang B. Modeling organ-specific vasculature with organ-on-a-chip devices. Nanotechnology. 2019;30(2): 024002 .

83. Nashimoto Y, Hayashi T, Kunita I, Nakamasu A, Torisawa YS, Nakayama M, et al. Integrating perfusable vascular networks with a three-dimensional tissue in a microfluidic device. Integr Biol (Camb). 2017;9(6):506-18.

84. Stevens KR, et al. In situ expansion of engineered human liver tissue in a mouse model of chronic liver disease. Sci Transl Med. 2017;9(399):eaah5505. https://doi.org/10.1126/scitranslmed. aah5505.

85. van Duinen V, Zhu D, Ramakers C, van Zonneveld AJ, Vulto P, Hankemeier T. Perfused 3D angiogenic sprouting in a highthroughput in vitro platform. Angiogenesis. 2019;22(1):157-65.

86. Rambol MH, Han E, Niklason LE. Microvessel network formation and interactions with pancreatic islets in three-dimensional chip cultures. Tissue Eng Part A. 2020;26:556-68.

87. Hrvatin S, O’Donnell CW, Deng F, Millman JR, Pagliuca FW, DiIorio P, et al. Differentiated human stem cells resemble fetal, not adult, beta cells. Proc Natl Acad Sci U S A. 2014;111(8):3038-43.

88. Rezania A, Bruin JE, Arora P, Rubin A, Batushansky I, Asadi A, et al. Reversal of diabetes with insulin-producing cells derived in vitro from human pluripotent stem cells. Nat Biotechnol. 2014;32(11):1121-33.

89. Pagliuca FW, Millman JR, Gürtler M, Segel M, van Dervort A, Ryu JH, et al. Generation of functional human pancreatic beta cells in vitro. Cell. 2014;159(2):428-39.

90. Russ HA, Parent AV, Ringler JJ, Hennings TG, Nair GG, Shveygert M, et al. Controlled induction of human pancreatic progenitors produces functional beta-like cells in vitro. EMBO J. 2015;34(13):1759-72.

91. Cebola I, Rodríguez-Seguí SA, Cho CHH, Bessa J, Rovira M, Luengo M, et al. TEAD and YAP regulate the enhancer network of human embryonic pancreatic progenitors. Nat Cell Biol. 2015;17(5):615-26.

92. Mamidi A, Prawiro C, Seymour PA, de Lichtenberg KH, Jackson A, Serup P, et al. Mechanosignalling via integrins directs fate decisions of pancreatic progenitors. Nature. 2018;564(7734): $114-8$.

93. Rosado-Olivieri EA, Anderson K, Kenty JH, Melton DA. YAP inhibition enhances the differentiation of functional stem cellderived insulin-producing beta cells. Nat Commun. 2019;10(1): 1464.

94. Nair GG, Liu JS, Russ HA, Tran S, Saxton MS, Chen R, et al. Recapitulating endocrine cell clustering in culture promotes maturation of human stem-cell-derived beta cells. Nat Cell Biol. 2019;21(2):263-74.
95. Velazco-Cruz L, Song J, Maxwell KG, Goedegebuure MM, Augsornworawat P, Hogrebe NJ, et al. Acquisition of dynamic function in human stem cell-derived beta cells. Stem Cell Rep. 2019;12(2):351-65.

96. Legoy TA, et al. Encapsulation boosts islet-cell signature in differentiating human induced pluripotent stem cells via integrin signalling. Sci Rep. 2020;10(1):414.

97. Aamodt KI, Powers AC. Signals in the pancreatic islet microenvironment influence beta-cell proliferation. Diabetes Obes Metab. 2017;19(Suppl 1):124-36.

98. Kao DI, Lacko LA, Ding BS, Huang C, Phung K, Gu G, et al. Endothelial cells control pancreatic cell fate at defined stages through EGFL7 signaling. Stem Cell Rep. 2015;4(2):181-9.

99. Eberhard D, Kragl M, Lammert E. 'Giving and taking': endothelial and beta-cells in the islets of Langerhans. Trends Endocrinol Metab. 2010;21(8):457-63.

100. Brissova M, Fowler MJ, Nicholson WE, Chu A, Hirshberg B, Harlan DM, et al. Assessment of human pancreatic islet architecture and composition by laser scanning confocal microscopy. J Histochem Cytochem. 2005;53(9):1087-97.

101. Di Cairano ES, et al. Neurotransmitters and neuropeptides: new players in the control of islet of Langerhans' cell mass and function. J Cell Physiol. 2016;231(4):756-67.

102. Briant LJB, Reinbothe TM, Spiliotis I, Miranda C, Rodriguez B, Rorsman P. Delta-cells and beta-cells are electrically coupled and regulate alpha-cell activity via somatostatin. J Physiol Lond. 2018;596(2):197-215.

103. Lebreton F, Lavallard V, Bellofatto K, Bonnet R, Wassmer CH, Perez L, et al. Insulin-producing organoids engineered from islet and amniotic epithelial cells to treat diabetes. Nat Commun. 2019;10(1):4491.

104. Li W, Nakanishi M, Zumsteg A, Shear M, Wright C, Melton DA, et al. In vivo reprogramming of pancreatic acinar cells to three islet endocrine subtypes. Elife. 2014;3:e1846.

105. Li W, Cavelti-Weder C, Zhang Y, Clement K, Donovan S, Gonzalez G, et al. Long-term persistence and development of induced pancreatic beta cells generated by lineage conversion of acinar cells. Nat Biotechnol. 2014;32(12):1223-30.

106. Houbracken I, et al. Lineage tracing evidence for transdifferentiation of acinar to duct cells and plasticity of human pancreas. Gastroenterology. 2011;141(2):731-41 741 e1-4.

107. Staels W, Heremans Y, Heimberg H. Reprogramming of human exocrine pancreas cells to beta cells. Best Pract Res Clin Endocrinol Metab. 2015;29(6):849-57.

108. Butler AE, Janson J, Bonner-Weir S, Ritzel R, Rizza RA, Butler PC. Beta-cell deficit and increased beta-cell apoptosis in humans with type 2 diabetes. Diabetes. 2003;52(1):102-10.

109. Butler AE, Cao-Minh L, Galasso R, Rizza RA, Corradin A, Cobelli $\mathrm{C}$, et al. Adaptive changes in pancreatic beta cell fractional area and beta cell turnover in human pregnancy. Diabetologia. 2010;53(10):2167-76.

110. Criscimanna A, et al. Duct cells contribute to regeneration of endocrine and acinar cells following pancreatic damage in adult mice. Gastroenterology. 2011;141(4):1451-62 1462 e1-6.

111. Van de Casteele M, et al. Neurogenin 3+ cells contribute to betacell neogenesis and proliferation in injured adult mouse pancreas. Cell Death Dis. 2013;4:e523.

112. Gershengorn MC, et al. Epithelial-to-mesenchymal transition generates proliferative human islet precursor cells. Science. 2004;306(5705):2261-4.

113. Gao R, Ustinov J, Pulkkinen MA, Lundin K, Korsgren O, Otonkoski T. Characterization of endocrine progenitor cells and critical factors for their differentiation in human adult pancreatic cell culture. Diabetes. 2003;52(8):2007-15.

114. Loomans CJM, Williams Giuliani N, Balak J, Ringnalda F, van Gurp L, Huch M, et al. Expansion of adult human pancreatic tissue 
yields organoids harboring progenitor cells with endocrine differentiation potential. Stem Cell Rep. 2018;10(3):712-24.

115. Halldorsson S, Lucumi E, Gómez-Sjöberg R, Fleming RMT. Advantages and challenges of microfluidic cell culture in polydimethylsiloxane devices. Biosens Bioelectron. 2015;63:218-31.

116. Regehr KJ, Domenech M, Koepsel JT, Carver KC, Ellison-Zelski SJ, Murphy WL, et al. Biological implications of polydimethylsiloxane-based microfluidic cell culture. Lab Chip. 2009;9(15):2132-9.

117. van Meer BJ, de Vries H, Firth KSA, van Weerd J, Tertoolen LGJ, Karperien HBJ, et al. Small molecule absorption by PDMS in the context of drug response bioassays. Biochem Biophys Res Commun. 2017;482(2):323-8

118. Bertelli E, Regoli M, Orazioli D, Bendayan M. Association between islets of Langerhans and pancreatic ductal system in adult rat. Where endocrine and exocrine meet together? Diabetologia. 2001;44(5):575-84.

119. Sunami E, et al. Morphological characteristics of Schwann cells in the islets of Langerhans of the murine pancreas. Arch Histol Cytol. 2001;64(2):191-201.

120. Baron M, Veres A, Wolock SL, Faust AL, Gaujoux R, Vetere A, et al. A single-cell transcriptomic map of the human and mouse pancreas reveals inter- and intra-cell population structure. Cell Syst. 2016;3(4):346-60 e4.

Publisher's Note Springer Nature remains neutral with regard to jurisdictional claims in published maps and institutional affiliations. 